\title{
Cladode size and collection time for pitahaya propagation
}

\section{Tamanho e época de coleta de cladódios para propagação de pitaya}

\author{
Maria Gabriela Fontanetti Rodrigues ${ }^{1 *}\left(\mathbb{D}\right.$, Antonio Flávio Arruda Ferreira ${ }^{2}$, Emely da Silva Malagutti ${ }^{3}$, \\ Milena dos Santos Pinto ${ }^{(\mathbb{D}}$, Laís Naiara Honorato Monteiro ${ }^{4} \mathbb{D}$, Marco Eustáquio de Sáa ${ }^{3}$
}

\author{
'Universidade Estadual Paulista "Julio de Mesquita Filho"/UNESP, Faculdade de Ciências Agrárias e Tecnológicas FCAT/UNESP, Dracena, SP, Brasil \\ 2Universidade Estadual do Mato Grosso/UNEMAT, Alta Floresta, Mato Grosso, Brasil \\ ${ }^{3}$ Universidade Estadual Paulista "Julio de Mesquita Filho"/UNESP, Faculdade de Engenharia de Ilha Solteira FEIS/UNESP, Ilha Solteira, SP, Brasil \\ "Universidade Estadual Paulista "Julio de Mesquita Filho"/UNESP, Faculdade de Ciências Agrárias FCA/UNESP, Botucatu, SP, Brasil \\ *Corresponding author: maria.gf.rodrigues@unesp.br \\ Received in March 8, 2021 and approved in May 27, 2021
}

\begin{abstract}
Cutting is a propagation method with the advantages of early production and uniform cultivation. Some factors influence propagation and rooting, such as the cutting size and the time of year the collection is performed. Thus, the present work aimed to evaluate the ideal size of white-fleshed red pitahaya cladodes and the time of their collection for crop propagation by cutting in view of the physiological quality of the produced clonal plants to enable more appropriate cultural management and increase the cultivation area. The experiment was conducted at the Faculty of Engineering (UNESP) using three cladode sizes (cuttings) with lengths of 10, 20 and $40 \mathrm{~cm}$ collected in two seasons (summer and winter). The experimental design used was completely randomized in a split-time scheme, with no dependence on the factors and 20 replicates. Evaluations of the biometric factors related to sprouts and cladode rooting were carried out 60 days after cutting. According to the results, there were significant differences among treatments, with a significant interaction of the number of sprouts. It can be concluded that, regarding the size of the cladodes, it is recommended, when possible, to use cladodes $40 \mathrm{~cm}$ in length; regarding the time of collection, it is recommended that collection be conducted in the winter period to favor the development of better-quality clonal plants.
\end{abstract}

Index terms: Hylocereus undatus Haw.; cuttings, clonal plant production; collection climate; exotic fruit production; sustainability.

\section{RESUMO}

A estaquia é o método de propagação que tem como vantagem a precocidade de produção e a uniformidade do cultivo. Alguns fatores influenciam na propagação e enraizamento dentre eles, o tamanho da estaca e a época do ano para sua coleta. Assim, o presente trabalho teve como objetivo avaliar o tamanho ideal de cladódios de pitaya vermelha com polpa branca (Hylocereus undatus Haw.), bem como a época de sua retirada na propagação da cultura por estaquia, tendo em vista a qualidade fisiológica de mudas produzidas, viabilizando manejos culturais mais adequados e incremento na área de cultivo. O experimento foi conduzido na Faculdade de Engenharia, Câmpus de Ilha Solteira - UNESP, utilizando três tamanhos de cladódios (estacas) com 10, 20 e $40 \mathrm{~cm}$ de comprimento, coletada em duas épocas (verão e inverno). O delineamento experimental utilizado foi inteiramente casualizado em esquema de parcelas sub-divididas no tempo, sem dependência dos fatores, com 20 repetições. As avaliações foram realizadas 60 dias após o estaqueamento, avaliando-se fatores biométricos relacionados às brotaç̃̃es e ao enraizamento dos cladódios. De acordo com os resultados, observa-se que houve diferença estatística entre os tratamentos, com interação significativa para número de brotos. Pode-se concluir que, quanto ao tamanho dos cladódios, recomenda-se, quando possível, a utilização daqueles com $40 \mathrm{~cm}$ e em relação à época de coleta, recomenda-se que seja feito no período de inverno, favorecendo o desenvolvimento de plantas clonais de melhor qualidade.

Termos para indexação: Hylocereus undatus; estaquia; produção de mudas clonadas; clima de coleta; produção de frutas exóticas; sustentabilidade.

\section{INTRODUCTION}

Considered a promising culture, the white-fleshed red pitahaya (Hylocereus undatus Haw.), also known as dragon fruit, is an exotic fruit tree belonging to the Cactaceae family; this plant originates from the tropical forest regions of Central and South America (Mizrahi; Nerd; Nobel, 1997).

In Brazil, consumption of this fruit has increased not only due to its exotic appearance but also due to its organoleptic characteristics, such as its sweetness, smooth flavor and low acid content (Moreira, 2012), as well as its 
antioxidant properties, high commercial value and rusticity (Marques et al., 2011; Ruths et al., 2019).

Thus, the search for new cultivation techniques to improve the exploitation of this fruit is of fundamental importance, with seedling production being the first step in obtaining quality fruits with high market value (Fernandes; Coutinho, 2019).

Among pitahaya propagation techniques, cutting stands out, as it enables the uniformity and quality of seedlings by cloning selected genotypes from mother plants in addition to eliminating the youth period (Hartmann et al., 2011; Zem et al., 2015).

The cutting length is a factor of great importance in the development of the adventitious root system, as larger cuttings have larger nutrient reserves that can be translocated to the base of the cutting and assist in root formation (Hartmann et al., 2011).

In addition, the cambial activity and endogenous level of auxin (IAA) in cuttings can be influenced by the time of year; therefore, the moment of collection is an important factor to be considered (Negishi et al., 2014).

For some species, any time of the year is favorable for the removal of cuttings; however, for others, the best time for removal is when the plants present low metabolism (dormancy) or when they present active growth (Hartmann et al., 2011). Thus, to increase the rooting percentage of cuttings, it is necessary to determine the optimal speciesspecific timing for the removal of branches (Hartmann et al., 2011) and the most appropriate cutting type to make seedling production viable (Santos et al., 2014).

In view of the above information, the present study aimed to evaluate the sizes of white-fleshed red pitahaya cladodes (e.g., H. undatus) collected in two seasons in view of the physiological quality of the resulting clonal plants, enabling more appropriate cultural management and increasing the cultivation area.

\section{MATERIAL AND METHODS}

This work was carried out in an experimental area belonging to the Laboratory of Seeds, Department of Phytotechnics, Food Technology and Socio-Economics, Faculty of Engineering of Ilha Solteira - FEIS/UNESP, located in the municipality of Ilha Solteira (SP); the geographical coordinates of the study are $51^{\circ} 06^{\prime} 35^{\prime \prime} \mathrm{W}$ in longitude and $20^{\circ} 38^{\prime} 44^{\prime \prime} \mathrm{S}$ in latitude, with an elevation of approximately $347 \mathrm{~m}$ a.s.l. The climate is classified as rainy and tropical, marked by summer rains and winter drought, with the annual average temperature reaching $28^{\circ} \mathrm{C}$ (Martins et al., 2015).
White-fleshed red pitahaya cladodes (e.g., $H$. undatus) were collected form plants previously produced by cuttings in commercial cultivation areas located in the municipality of Tupi Paulista - São Paulo State; the geographical coordinates of this location are $21^{\circ} 22^{\prime} 52^{\prime \prime S}$ and $51^{\circ} 34^{\prime} 14^{\prime \prime} \mathrm{W}$, with an average elevation of $400 \mathrm{~m}$ a.s.l.

The experimental design used in this study was completely randomized, with a split-time scheme, no dependence on the factors, and 20 replicates per treatment. Each collected cladode was considered one replicate, and two collection periods (subplot factor) were considered: summer (February) and winter (June) (Figure 1); three cladode sizes (main plot factor) were considered: 10, 20 and $40 \mathrm{~cm}$ (Figure 2).

The bases of the cladodes were previously treated with $2 \%$ Bordeaux mixture by immersion, with subsequent cutting without any plant growth regulators at a depth of $5 \mathrm{~cm}$ in plastic pots filled with organic compost of the vegetable soil type; manual sprinkler irrigation was performed whenever necessary to maintain the substrate in its field capacity, and the plants were kept in full sun.

A soil analysis of the substrates produced the following values: $\mathrm{P}=329 \mathrm{mg} / \mathrm{dm}^{3} ; \mathrm{O} . \mathrm{M} .=59 \mathrm{~g} / \mathrm{dm}^{3}$; pH 6.4; $\mathrm{K}=4.3 \mathrm{mmolc} / \mathrm{dm}^{3} ; \mathrm{Ca}=172 \mathrm{mmolc} / \mathrm{dm}^{3} ; \mathrm{Mg}=$ $101 \mathrm{mmolc} / \mathrm{dm}^{3} ;(\mathrm{H}+\mathrm{Al})=15 \mathrm{mmolc} / \mathrm{dm}^{3} ; \mathrm{CEC}=292.3$ mmolc $/ \mathrm{dm}^{3} ; \mathrm{V}=95 \%$; all values were considered optimal for the purpose of the study.

Evaluations were carried out 60 days after cutting by analyzing the following parameters: the number of sprouts (NS), obtained by counting the number of new sprouts emitted per cladode; the sprouting percentage (SP); the rooting percentage (RP); the length of the longest sprout (LLS) $(\mathrm{cm})$; the diameter of the longest sprout (DLS) $(\mathrm{cm})$; the length of the longest root (LLR) (cm); and the total fresh mass (TFM) and total dry mass (TDM) of the cuttings, in grams $(\mathrm{g})$ per seedling.

The total dry mass was obtained by drying the clonal plants in an oven with forced air circulation at $60{ }^{\circ} \mathrm{C}$ for 160 hours until a constant mass was obtained; the masses were measured on a precision analytical scale $(0.0001 \mathrm{~g})$.

The data were analyzed using SISVAR software (Ferreira, 2014). The normality hypothesis was tested by the Shapiro-Wilk test, and the F test was used in the analysis of variance to detect differences among factors and to compare their means when significant differences were found for two-level factors (time). For factors with three levels (cladode size), Tukey's test was used to compare the means of the treatments when a significant difference was found for each variable. All statistical tests were performed at $5 \%$ probability. 


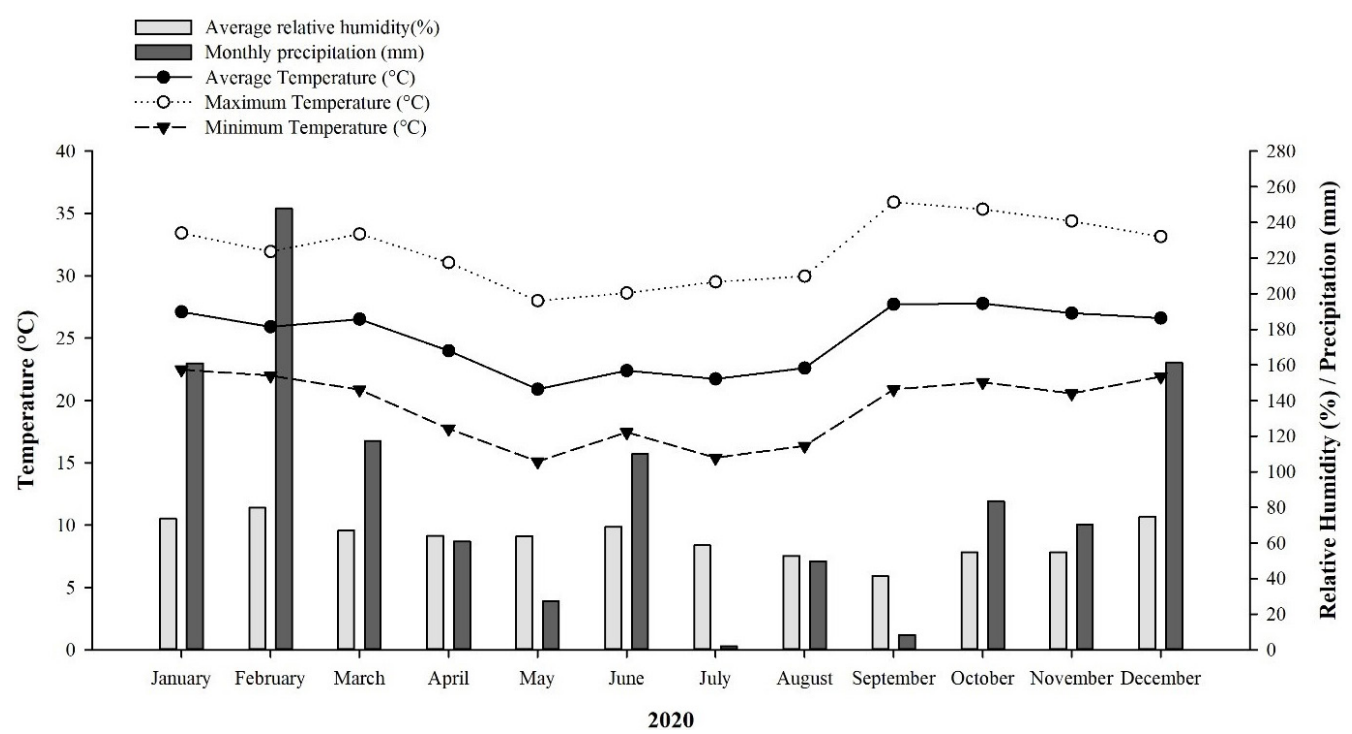

Figure 1: Monthly maximum, average and minimum temperatures $\left({ }^{\circ} \mathrm{C}\right)$ and relative humidity $(\%)$ and the monthly precipitation totals $(\mathrm{mm})$ of the microregion of Dracena.

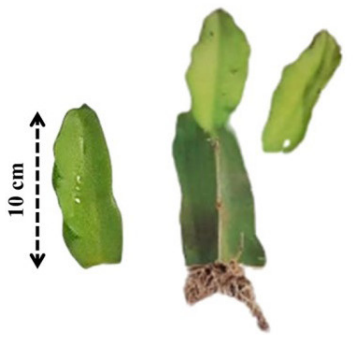

B

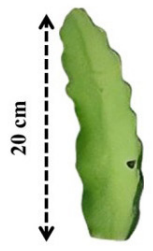

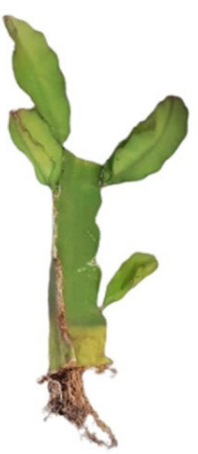

C
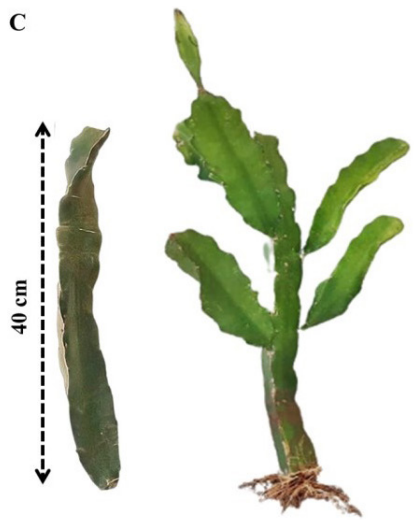

Figure 2: Cladode sizes $(A=10 \mathrm{~cm}, B=20 \mathrm{~cm}$ and $C=40 \mathrm{~cm})$ used for the cutting and sprouting of white-fleshed red pitahaya (e.g., H. undatus).

\section{RESULTS AND DISCUSSION}

The results of the analysis of variance of the data obtained from the studied variables of clonal plants propagated from white-fleshed red pitahaya cladodes (Hylocereus undatus) are shown in Table 1; significant differences existed among treatments, with significant interactions observed in the number of sprouts.

Table 2 shows that both the cladode size and collection time influenced the number of sprouts emitted; the number was greatest in cladodes $40 \mathrm{~cm}$ in length which were collected during the winter period, with an average of 4.55 sprouts.
Analyzing only the cladode size, a positive relationship was observed between the number of sprouts and sprouting percentage in the cladodes of the greatest studied lengths; this result corroborates the analyses carried out by Moreira et al. (2017), who studied the determination of the cutting length for the production of clonal pitahaya plants (Hylocereus costaricensis) in protected environments and observed that clonal plants formed from cladodes of greater lengths presented higher reserves and stored nutrient availabilities (Delgado; Yuyama, 2010), mainly carbohydrates, which directly contribute to the formation and growth of sprouts and roots (Nicoloso; Cassol; Fortunat, 2001). 
Table 1: Analysis of variance of the number of sprouts (NS), sprouting percentage (SP), length of the longest sprout (LLS), diameter of the longest sprout (DSP), rooting percentage (RP), length of the longest root (LLR), total fresh mass (TFM) and total dry mass (TDM) of clonal red pitahaya plants (Hylocereus undatus) propagated by cladodes of different sizes and collection times.

\begin{tabular}{|c|c|c|c|c|}
\hline \multirow{2}{*}{ Source of Variation } & $\mathrm{NS}^{1}$ & SP & $\operatorname{LLS}(\mathrm{cm})$ & $\mathrm{DSP}(\mathrm{cm})$ \\
\hline & \multicolumn{4}{|c|}{ Mean Square } \\
\hline Size $(\mathrm{T})$ & $2.5043^{*}$ & $1187.5000^{N S}$ & $1086.6804^{*}$ & $37.4497 *$ \\
\hline Time $(E)$ & $3.5864 *$ & $2083.3333^{*}$ & 1388.1182* & $69.2816^{*}$ \\
\hline$T \times E$ & $1.5790 *$ & $145.8333^{\mathrm{NS}}$ & $53.1091^{\text {NS }}$ & $5.4838^{\mathrm{NS}}$ \\
\hline CV1\% & 30.97 & 21.48 & 61.23 & 54.43 \\
\hline CV2\% & 25.49 & 9.30 & 68.14 & 48.37 \\
\hline General Average & 1.51 & 85.00 & 11.24 & 3.09 \\
\hline \multirow{2}{*}{ Source of Variation } & $\mathrm{RP}$ & $\operatorname{LLR}(\mathrm{cm})$ & TFM (g) & TDM (g) \\
\hline & \multicolumn{4}{|c|}{ Mean Square } \\
\hline Size $(T)$ & $395.8333^{*}$ & $449.2623^{*}$ & $0.5569 *$ & $0.0065^{*}$ \\
\hline Time $(E)$ & $187.5000^{\mathrm{NS}}$ & $33.2853^{\mathrm{NS}}$ & $0.0347^{*}$ & $0.0009 *$ \\
\hline$T \times E$ & $187.5000^{\mathrm{NS}}$ & $72.1303^{N S}$ & $0.0136^{\mathrm{NS}}$ & $0.0001^{\mathrm{NS}}$ \\
\hline CV1\% & 9.69 & 58.45 & 61.77 & 47.26 \\
\hline CV2\% & 9.69 & 55.94 & 45.82 & 35.24 \\
\hline General Average & 94.17 & 11.73 & 0.1601 & 0.0158 \\
\hline
\end{tabular}

* Significant and Ns Not significant by the $F$ test at a $5 \%$ probability. ${ }^{1}$ Values transformed by the $\sqrt{ }(x+0.5)$ equation.

Thus, in cases where there is greater availability of material, the use of larger cladodes is recommended, since according to Balaguera-Lopez et al. (2010), a greater cladode length allows a plant to reach the apex of the tutor and begin emitting secondary branches more quickly, with adult plants forming earlier, initiating the reproductive stage.

However, when analyzing the collection time of the cladodes, it was observed that pitahaya, despite being a plant with typically herbaceous branches (cladodes), the cutting of which is recommended in spring/summer when branches have low tissue lignification degrees and high meristematic activity (Franzon; Carpenedo; Silva, 2010), has the behavior of plants that present vegetative rest; in vegetative rest, vegetative growth stops and, consequently, there is greater accumulation of reserves, since cladodes removed in winter showed higher numbers of sprouts and higher sprouting percentages. Another factor that may be involved in this result is the water condition of the cladodes, as the summer collection season corresponds to a period of higher temperatures, causing the cladodes to lose water more easily due to transpiration (Pizzatto et al., 2011), affecting sprouting.
As shown in Table 2, regarding the length and diameter of the longest bud, it can be seen that, in both collection periods, positive correlations were found between these variables and the size of the cladodes; the highest values were obtained for 40-cm-long cladodes that were removed in winter, with average lengths and diameters of 18.41 and $5.00 \mathrm{~cm}$, respectively; although the interactions between these factors were not significantly different. This result corroborates the findings of Moreira et al. (2017), who concluded that the length of pitaya cladodes influenced the height gain, length and diameter of the emitted shoots, presenting a positive linear relationship; that is, the higher the stake was, the greater the increments were.

In addition, by analyzing only the collection times of the cladodes, it was observed that the winter period was statistically superior to the summer period and significantly influenced the obtained results.

Table 3 shows that the same patterns were observed when analyzing the fresh and dry masses of the resulting clonal plants; as expected, the cladodes with greater lengths provided the highest values of these two variables. However, in this case, it was also verified that 
the winter period was statistically superior to the summer period, with fresh mass values varying from $0.07 \mathrm{~g}$ to $0.29 \mathrm{~g}$ and dry mass values varying from 0.006 to 0.030 $\mathrm{g}$, indicating, once again, that pitahaya plants present vegetative rest behavior, with greater accumulations of reserves in winter than in summer.

When analyzing the interaction between the collection time and cladode length as they affect the rooting percentage, no significant influence was observed, and an overall rooting average of $94.17 \%$ was obtained (Table 1).

Table 2: Number of sprouts (NS), sprouting percentage $(\mathrm{SP})$, length of the longest sprout (LLS), and diameter of the longest sprout (DLS) of white-fleshed red pitahaya cladodes (Hylocereus undatus) propagated by cladodes of different sizes and collection times.

\begin{tabular}{|c|c|c|c|}
\hline \multirow{3}{*}{ Size (cm) } & \multicolumn{2}{|c|}{ Collection time } & \multirow{3}{*}{ Mean } \\
\hline & Summer & Winter & \\
\hline & \multicolumn{2}{|c|}{ NS } & \\
\hline 10 & $1.25 \mathrm{Aa}^{*}$ & 1.40 Ba & $1.33 \mathrm{~B}$ \\
\hline 20 & $1.60 \mathrm{Aa}$ & $2.00 \mathrm{Ba}$ & $1.80 \mathrm{~B}$ \\
\hline 40 & $1.55 \mathrm{Ab}$ & 4.55 Aa & $3.05 \mathrm{~A}$ \\
\hline Mean & $1.47 \mathrm{~b}$ & $2.65 \mathrm{a}$ & \\
\hline Size $(\mathrm{cm})$ & \multicolumn{2}{|c|}{$\mathrm{SP}$} & Mean \\
\hline 10 & 60.00 & 85.00 & 72.50 \\
\hline 20 & 85.00 & 95.00 & 90.00 \\
\hline 40 & 85.00 & 100.00 & 92.50 \\
\hline Mean & $76.67 \mathrm{~b}$ & $93.33 \mathrm{a}$ & \\
\hline Size $(\mathrm{cm})$ & \multicolumn{2}{|c|}{ LLS } & Mean \\
\hline 10 & 7.41 & 9.76 & $8.78 \mathrm{~B}$ \\
\hline 20 & 7.88 & 14.29 & $11.26 \mathrm{~B}$ \\
\hline 40 & 14.57 & 18.41 & $16.65 \mathrm{~A}$ \\
\hline Mean & $10.23 \mathrm{~b}$ & $14.39 \mathrm{a}$ & \\
\hline Size $(\mathrm{cm})$ & \multicolumn{2}{|c|}{ DLS } & Mean \\
\hline 10 & 3.04 & 2.94 & $2.98 \mathrm{~B}$ \\
\hline 20 & 2.33 & 4.25 & $3.34 \mathrm{~B}$ \\
\hline 40 & 3.75 & 5.00 & $4.43 \mathrm{~A}$ \\
\hline Mean & $3.04 \mathrm{~b}$ & $4.12 \mathrm{a}$ & \\
\hline
\end{tabular}

* Different capital letters between rows in the column differ according to Tukey's test. Different lowercase letters between columns in the row differ by the $\mathrm{F}$ test, both at a $5 \%$ probability.
Table 3: Rooting percentage (RP), total fresh mass (TFM), total dry mass (TDM) and length of the longest root (LLR) of white-fleshed red pitahaya (Hylocereus undatus) plants propagated by cladodes of different sizes and collection times.

\begin{tabular}{|c|c|c|c|}
\hline \multirow{2}{*}{ Size $(\mathrm{cm})$} & \multicolumn{2}{|c|}{ Collection time } & \multirow{2}{*}{ Mean } \\
\hline & Summer & Winter & \\
\hline Size (cm) & \multicolumn{2}{|c|}{$\mathrm{RP}$} & Mean \\
\hline 10 & 95.00 & 95.00 & $95.00 \mathrm{AB}$ \\
\hline 20 & 80.00 & 95.00 & $87.50 \mathrm{~B}$ \\
\hline 40 & 100.00 & 100.00 & $100.00 \mathrm{~A}$ \\
\hline \multirow[t]{2}{*}{ Mean } & 96.67 & 91.67 & \\
\hline & \multicolumn{2}{|c|}{ TFM } & Mean \\
\hline 10 & 0.0681 & 0.0705 & $0.0693 \mathrm{~B}$ \\
\hline 20 & 0.1050 & 0.1301 & $0.1175 \mathrm{~B}$ \\
\hline 40 & 0.2562 & 0.3307 & $0.2934 \mathrm{~A}$ \\
\hline Mean & $0.1431 \mathrm{~b}$ & $0.1771 \mathrm{a}$ & \\
\hline Size $(\mathrm{cm})$ & \multicolumn{2}{|c|}{ TDM } & Mean \\
\hline 10 & 0.0039 & 0.0077 & $0.0058 \mathrm{C}$ \\
\hline 20 & 0.0094 & 0.0136 & $0.0115 \mathrm{~B}$ \\
\hline 40 & 0.0259 & 0.0343 & $0.0301 \mathrm{~A}$ \\
\hline Mean & $0.0131 \mathrm{~b}$ & $0.0185 a$ & \\
\hline Size $(\mathrm{cm})$ & \multicolumn{2}{|c|}{ LLR } & Mean \\
\hline 10 & 8.67 & 10.67 & $9.67 \mathrm{~B}$ \\
\hline 20 & 10.99 & 8.80 & $9.94 \mathrm{~B}$ \\
\hline 40 & 17.13 & 14.08 & $15.60 \mathrm{~A}$ \\
\hline Mean & 12.26 & 11.21 & \\
\hline
\end{tabular}

* Different capital letters among rows in the right column differ according to Tukey's test. Different lowercase letters between columns in the rows differ according to the $\mathrm{F}$ test, both at a $5 \%$ probability.

The high rooting percentage obtained for the cladodes may have been due to the carbon/nitrogen ratio and the hormonal balance of auxins being suitable for the root formation process; in addition, this result is related to the fact that the studied species is a cactus presenting a succulent stem that stores nutrients and water and survives over long periods (Marques et al., 2011; Lone; Takahashi, 2019).

In addition to this variable, when analyzing only the cladode size, it was observed that 40 -cm-long cladodes, regardless of the collection time, showed the highest rooting percentages, with $100 \%$ rooting (Table 3 ); this result corroborates the data found by Bastos et al. (2006), 
who observed that $25-\mathrm{cm}$-long cladodes had significantly higher rooting percentages than $15.0-\mathrm{cm}-$ long cladodes, both of which had undergone IBA applications of 3000 $\mathrm{mg} \mathrm{L}^{-1}$ and had not undergone plant growth regulator application.

Additionally, regarding the length of the longest root, although the highest value, $15.60 \mathrm{~cm}$, was also observed with the $40-\mathrm{cm}$-long cladodes, this result was significantly different from the other treatments.

The size of cuttings is related to their nutritional condition, with the amount of reserves and the number of buds varying according to the length used; normally, cuttings with greater lengths may have higher carbohydrate and endogenous auxin contents (Mayer; Pereira; Nachtigal, 2002). According to Fachinello, Hoffmann and Nachtigal (2005), a high carbohydrate content, in addition to providing a source of carbon for the biosynthesis of nucleic acids and proteins used in root production, may favor an increase in the $\mathrm{C} / \mathrm{N}$ ratio, including greater rooting.

Additionally, it is known that the presence of leaves and buds in cuttings plays a key role in the formation of new root systems, and these factors are responsible for the production of assimilates and substances such as auxins, which is synthesized in these locations (Taiz; Zeiger, 2017); this analysis shows the high capacity of pitahaya wood cladodes to remain alive.

\section{CONCLUSIONS}

Regarding the size of the cladodes, it is recommended, when possible, that $40-\mathrm{cm}-1$ long cladodes are used; regarding the time of collection, it is recommended that collection be performed in the winter period to favor the development of better-quality clonal plants.

\section{ACKNOWLEDGMENTS}

To the São Paulo State Research Support Foundation (FAPESP) for the master's scholarship granted to the first author (Process Number 2018/01671-0), and to the Faculty of the College of Agricultural Technological and Sciences of Dracena (FCAT/UNESP).

\section{REFERENCES}

BALAGUERA-LÓPEZ, H. E. et al. El tamaño del cladodio y los niveles de auxina influyen en la propagación asexual de pitaya (Selenicereus megalanthus Haw.). Revista Colombiana de Ciencias Hortícolas, 4(1):33-42, 2010.
BASTOS, D. C. et al. Propagação da pitaya 'vermelha' por estaquia. Ciência e Agrotecnologia, 30(6):1106-1109, 2006.

DELGADO, J. P. M.; YUYAMA, K. Comprimento de estaca de camu-camu com ácido indolbutírico para a formação de mudas. Revista Brasileira de Fruticultura, 32(2):522526, 2010.

FACHINELLO, J. C.; HOFFMANN, A.; NACHTIGAL, J. C. Propagação de plantas frutíferas. Brasília: Embrapa Informação Tecnológica, 2005. 221p.

FERNANDES, A. C.; COUTINHO, G. Nitrogênio no desenvolvimento inicial de mudas de pitaya vermelha. Global Science and Technology, 12(3):32-43, 2019.

FERREIRA, D. F. Sisvar: A guide for its bootstrap procedures in multiple comparisons. Ciência e Agrotecnologia, 38(2):109-112, 2014.

FRANZON, R. C.; CARPENEdO, S.; SILVA, J. C. S. Produção de mudas: Principais técnicas utilizadas na propagação de fruteiras. (Documento 283), Planaltina, DF: Embrapa Cerrados, 2010. 56p.

HARTMANN, H. T. et al. Plant propagation: Principles and practices. 8th ed. New Jersey: Prentice-Hall, 2011. 915p.

LONE, A. B.; TAKAHASHI, L. S. A. Enraizamento e brotação de estacas de pitaya em diferentes períodos do ano. Revista Técnico-Científica do CREA-PR, (22):1-13, 2019.

MARQUES, V. B. et al. Tamanho de cladódios na produção de mudas de Pitaia vermelha. Revista Caatinga, 24(4):50-54, 2011.

MARTINS, M. et al. Avaliação das condições socioeconômicas e ambientas de propriedades agrícolas do município de Ilha Solteira - São Paulo, Brasil. HOLOS Environment, 15(1):1-9, 2015.

MAYER, N. A.; PEREIRA, F. M.; NACHTIGAL, J. C. Efeito do comprimento de estacas herbáceas de dois clones de umezeiro (Prunus mume Sieb \& Zucc.) no enraizamento adventício. Revista Brasileira de Fruticultura, 24(2):500-504, 2002.

MIZRAHI, Y.; NERD, A.; NOBEL, P. S. Cacti as crops. Horticultural Review, 18:291-320, 1997.

MOREIRA, A. R. et al. Determinação do comprimento da estaca para produção de mudas de pitaia (Hylocereus costaricensis) em ambiente protegido. TECNO-LÓGICA, 21(2):41-45, 2017. 
MOREIRA, R. A. Cultivo da pitaia: Implantação. (Boletim Técnico $n^{\circ}$ 92). Universidade Federal de Lavras Departamento da Agricultura, p.1-16, 2012.

NEGISHI, N. et al. Hormone level analysis on adventitious root formation in Eucalyptus globulus. New Forests, 45:577587, 2014.

NICOLOSO, F. T.; CASSOL, L. F.; FORTUNATO, R. P. Comprimento da estaca de ramo no enraizamento de ginseng brasileiro (Pfaffia glomerata). Ciência Rural, 31(1):57-66, 2001.

PIZZATTO, M. et al. Influência do uso de AIB, época de coleta e tamanho de estaca na propagação vegetativa de hibisco por estaquia. Revista Ceres, 58(4):487-492, 2011.
RUTHS, R. et al. Influência da temperatura e luminosidade na germinação de sementes das espécies: Selenicereus setaceus, Hylocereus undatus e Hylocereus polyrhizus. Revista de Ciências Agroveterinárias, 18(2):194-201, 2019.

SANTOS, L. W. et al. Propagação vegetativa de mulungu (Erythrina velutina Willd. - Fabaceae). Revista Brasileira de Ciências Agrárias, 9(3):420-426, 2014.

TAIZ, L. et al. Fisiologia e desenvolvimento vegetal. 6.ed. Porto Alegre: Artmed, 2017. 888p.

ZEM, L. M. et al. Enraizamento de estacas semilenhosas de cataia coletadas em quatro estações. Ciência Rural, 45(10):1815-1818, 2015. 